\title{
Tracing the sources of sulfur in Beijing soils with stable sulfur isotopes
}

\section{Qingjun Guo ${ }^{\mathrm{a}, *}$, Guangxu Zhu ${ }^{\mathrm{a}, \mathrm{b}}$, Harald Strauss ${ }^{\mathrm{c}}$, Marc Peters ${ }^{\mathrm{a}}$, Tongbin Chen ${ }^{\mathrm{a}}$, Junxing Yang ${ }^{\mathrm{a}}$, Rongfei Wei ${ }^{\mathrm{a}}$,} Liyan Tian ${ }^{\mathrm{a}}$, Xiaokun Han $^{\mathrm{a}}$

a Center for Environmental Remediation, Institute of Geographic Sciences and Natural Resources Research, Chinese Academy of Sciences, Beijing 100101, China

b State Key Laboratory of Environmental Geochemistry, Institute of Geochemistry, Chinese Academy of Sciences, Guiyang 550002, China

${ }^{\mathrm{c}}$ Institut für Geologie und Paläontologie, Westfälische Wilhelms-Universität Münster, Corrensstr. 24, 48149 Münster, Germany

\section{A R T I C L E I N F O}

\section{Article history:}

Received 3 June 2015

Revised 24 October 2015

Accepted 24 November 2015

Available online 25 November 2015

\section{Keywords:}

Sources

Industrial and non-industrial area

Different sulfur isotope species

Beijing

\begin{abstract}
A B S T R A C T
Stable sulfur isotope analyses were applied in order to trace local sulfur sources and to identify sulfur turnover rates in Beijing soil. Anthropogenic sources and atmospheric deposition are the main processes responsible for the occurrence of sulfide, organic and sulfate sulfur in three soil profiles located in the vicinity of a steel company in Beijing, China. This input results in an atypical invariable sulfur isotopic composition along the vertical profiles. The $\delta^{34} \mathrm{~S}$ values of soil sulfate from the industrial area revealed that both the topsoil and deep soil have been affected by industrial activities. Three soil profiles from non-industrial areas displayed vertical patterns in both sulfur abundance and sulfur isotopic composition, indicative for (close to) natural soils.

Eight soil profiles collected in Beijing and their vertical distribution of different sulfur species, concentrations and sulfur isotopic compositions reveal both anthropogenic and natural contributions.
\end{abstract}

C 2015 Elsevier B.V. All rights reserved.

\section{Introduction}

The fast economic development of Beijing in the past few decades, and the subsequent industrial, communal and agricultural contributions have affected the environment in this region. Soil is a prime recipient for industrial, communal and agricultural input. The release of sulfur dioxide and particles by coal combustion especially in industrial areas, constitutes a serious perturbation to the pre-existent environmental geochemical sulfur cycle, and contributes to atmospheric pollution and acid rain deposition. Usually, there are six main inputs of sulfur (S) into soil: (i) atmospheric deposition (Legge and Krouse, 1992), (ii) weathering of parent material (Knöller et al., 2004; Migazewski et al., 2013, 2015), (iii) application of S-containing fertilizers, manure and sewage (Otero and Soler, 2002; Szynkiewicz et al., 2011), (iv) plant and animal residues (Legge and Krouse, 1992), (v) CS (carbon, sulfur)mineralization in humic-mixed soils and debris covers under aerated conditions (e.g. Novák et al., 2001, 2004; Knöller et al., 2005; Shanley et al., 2005), and (vi) anaerobic bacterial (dissimilatory) reduction (BSR) of sulfates derived from different sources (e.g. Mayer et al., 1995, 2004; Galuszka, 2005). Despite an established understanding of these inputs, the development/application of effective methods for tracing the sources of sulfur in soil are still posing a challenge.

The application of stable isotope analyses on $\mathrm{S}$ compounds in different environments for tracing the source of sulfur is a growing field (Legge and Krouse, 1992; Thompson and Bottrell, 1998; Chu, 2000; Xiao and Liu, 2002; Novák et al., 2001, 2004; Knöller et al., 2004; Liu

\footnotetext{
* Corresponding author.

E-mail address: guoqj@igsnrr.ac.cn (Q. Guo).
}

et al., 2008; Migazewski et al., 2013, 2015). The $\delta^{34}$ S variations among different $\mathrm{S}$ compounds can be attributed to isotopic selectivity in biochemical transformations or to different $\mathrm{S}$ sources.

From a number of previous studies, it was concluded that besides the concentration and duration of exposure to the source (Krouse et al. 1984, 1991; Legge and Krouse, 1992), the amount of plant cover (Krouse, 1989; Winner et al., 1981), soil type and texture (Krouse and Tabatabai, 1986; Krouse et al., 1991), S amounts in the soil (Mayer, 1993), and net drainage Krouse (1989)) are the major factors which determine the depth of penetration of anthropogenic $S$ into the soil (Legge and Krouse, 1992).

There are different sulfur species existing in soil samples, including (1) soluble $S$ which is represented by monosulfides and soluble sulfate; (2) chromium reducible S (CRS), consisting primarily of pyrite sulfur; and (3) organically bound sulfur (OBS). A large number of detailed studies have shown that $\mathrm{SO}_{4}^{2-}$ strongly interacts with soils, and participates in a complex organic-inorganic soil S cycle (Van Stempvoort et al., 1992; Zhang, 2009). Through analyzing the sulfur isotope composition of $\mathrm{SO}_{4}^{2-}$ in soil, the sources of sulfur can be traced.

A few articles (Legge and Krouse, 1992; Thompson and Bottrell, 1998) have focused on the usefulness of different sulfur isotope techniques applied on distinct sulfur species from the four compartments of the global environment: atmosphere, biosphere, hydrosphere, and lithosphere.

In this study, the stable isotope investigations of different sulfur compounds in soil and water will be used for tracing the sources of sulfur in Beijing soils and compare soil profiles from non-industrial and industrial areas and water samples from Beijing in order to identify natural and anthropogenic processes, which influence the soil sulfur cycle. 


\section{Study area, sampling, and analytical methods}

\subsection{Study area}

Beijing $\left(39^{\circ} 20^{\prime}-40^{\circ} 90^{\prime} \mathrm{N}, 115^{\circ} 20^{\prime}-117^{\circ} 20^{\prime} \mathrm{E}\right)$ is located in North China (Fig. 1). The mountains in the west and north of Beijing consist of Lower Paleozoic rocks (Xie, 1990). The city was built on the northern tip of the North China Plain, at an elevation between 40 and $60 \mathrm{~m}$ above sea level. The climate is humid continental, driven by the monsoon, and characterized by hot and humid summers as well as generally cold, dry and windy winters. The average temperatures are $1.6^{\circ} \mathrm{C}$ in January and $30.8^{\circ} \mathrm{C}$ in July.

\subsection{Sampling}

In total, 112 soil samples were collected from eight soil profiles at eight different sites in Beijing (Fig. 1; Table S1) (Guo et al., 2013). Soil sampling was performed using a hand-held soil sampler.

Soil profiles A, B and C (DLC) are located in the Beijing Steel Company (Guo et al., 2013).

The FCK profile (D) and the 469 profile (E) are located outside of the main area of the Beijing Steel Company (Guo et al., 2013).

The Tongzhou profile (F), the Yongledian profile $(G)$, and the Guadi profile $(\mathrm{H})$ are situated in the Beijing countryside (Guo et al., 2013).

Four coal samples were collected from the Beijing Steel Company (Table S2).

Eleven lake water samples were separately collected in January and May 2010 from six lakes (Jishuitan lake (JST), Zizhuyuan lake (ZZY), Yiheyuan lake (YHY), Chuandongyuan lake (CDY), Weiminghu lake (WMH), Yuanmingyuan lake (YMY)) in the Beijing urban area (Table S2).

Six rain water samples were separately collected in August and October 2010 from the top of the main building of the Institute of Geographic Sciences and Natural Resources Research, Chinese Academy of Sciences, Beijing (Table S2).

\subsection{Analytical methods}

The soil samples were analyzed for their $\mathrm{C}$ and $\mathrm{S}$ abundance and the isotopic composition of different S-bearing phases.

Soil and coal samples were dried at room temperature and grinded. The content of soil organic carbon (SOC) (SOC $=\mathrm{TC}-\mathrm{TIC}$ ) was determined as the difference between total carbon (TC) and total inorganic carbon (TIC). These were measured using IR spectroscopy following the liberation of carbon dioxide from soil samples via combustion at $1350{ }^{\circ} \mathrm{C}$ (TC) or acid-digestion (TIC). Analyses were performed using a CS Mat 5500 at the Institut für Geologie und Paläontologie, University of Münster, Germany, standard deviation for the sulfur abundance was \pm 0.03 wt.\%.

Concentration measurements of water samples on anions were analyzed by gas chromatography using an AMS Smartchem $300 \circledR$ in the laboratories of the Institute of Geographic Sciences and Natural Resources Research, Beijing, China. Analytical precision was better than $\pm 5 \%$.

Lake and rain water samples were first filtered using $0.45 \mu \mathrm{m}$ cellulose nitrate filters, and sulfate was subsequently extracted from the solution via precipitation as barium sulfate $\left(\mathrm{BaSO}_{4}\right)$ after adding $\mathrm{BaCl}_{2}$ using standard procedures (e.g. Dogramaci et al., 2001).

For sulfur isotope analyses of the soil samples, three sulfur species were extracted from the soil by sequential extraction: (1) soluble $S$ represented by monosulfides and soluble sulfate, (2) chromium reducible $S$ (CRS) consisting primarily of pyrite sulfur, and (3) organically bound sulfur (OBS).First, the CRS was liberated through a $\mathrm{HCl}$ solution and a hot $1.0 \mathrm{~mol} / \mathrm{L} \mathrm{CrCl}_{2}$ solution. Resulting $\mathrm{H}_{2} \mathrm{~S}$ from both steps was precipitated as $\mathrm{ZnS}$ and thereafter transformed to $\mathrm{Ag}_{2} \mathrm{~S}$ with $0.1 \mathrm{~mol} / \mathrm{L} \mathrm{AgNO}_{3}$ solution (Canfield et al., 1986). In the second stage, the sample residue was filtered, soluble sulfate was extracted from the solution and precipitated as barium sulfate $\left(\mathrm{BaSO}_{4}\right)$ after adding $\mathrm{BaCl}_{2}$ using standard procedures. Finally, the solid residue was thoroughly mixed with Eschka powder (ASTM, 1977) and combusted at $800{ }^{\circ} \mathrm{C}$ in order to oxidize any residual sulfur. This final fraction represents organic bound sulfur (OBS), which was precipitated as $\mathrm{BaSO}_{4}$, using a $\mathrm{BaCl}_{2}$, solution. Sulfate was measured as a trace constituent in soils.

The sulfur isotopic composition from $\mathrm{BaSO}_{4}$ and $\mathrm{Ag}_{2} \mathrm{~S}$ was precipitates measured with a Finnigan Delta V Plus mass spectrometer equipped with an elemental analyzer at the Institut für Geologie und Paläontologie, University of Münster, Germany. Results are reported in the standard delta notation against the Canyon Diablo troilite standard (VCDT). Reproducibility was better than $\pm 0.3 \%$.

\section{Results}

Analytical results are presented in Tables. S1 and S2 and plotted in Figs. 2-5. The total sulfur content of the collected soil samples was less than $1 \mathrm{wt}$. $-\%$. The $\delta^{34} \mathrm{~S}$ values of organic sulfur are rather homogeneous: $\delta^{34} \mathrm{~S}_{\mathrm{OBS}}$ values vary from $2.8 \%$ 。 to $6.5 \%$ 。 $(5.1 \pm 1.5 \%$, $\mathrm{n}=5$, VCDT $)$.

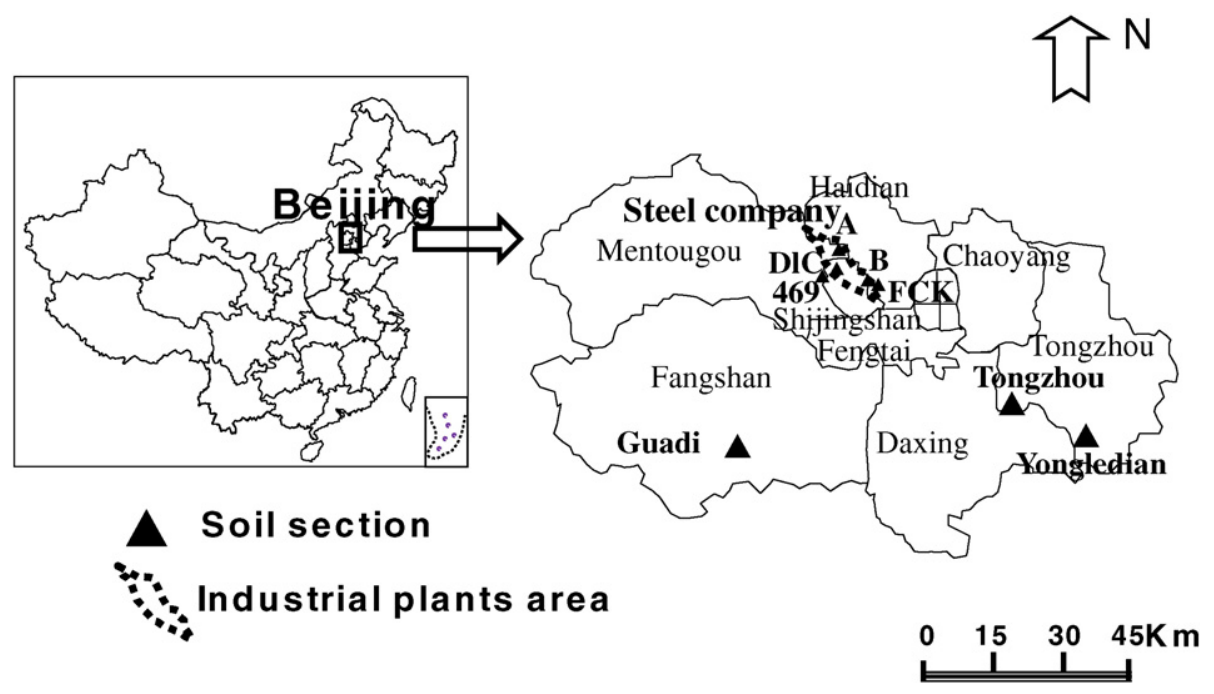

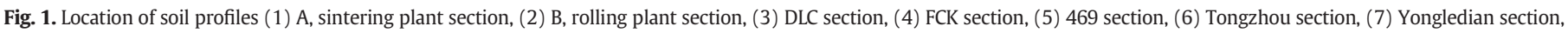
(8) Guadi section, Beijing city, China. 


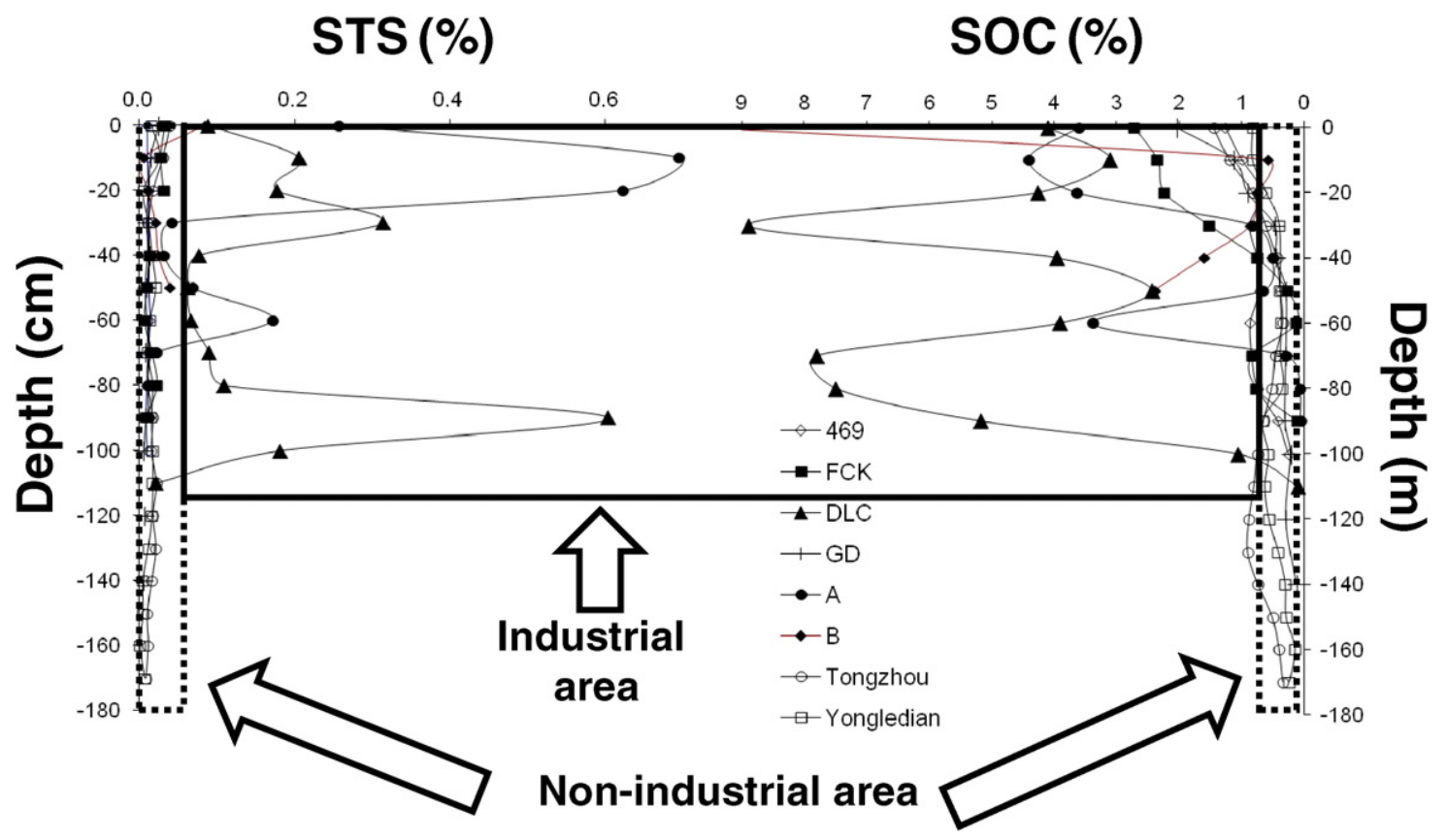

Fig. 2. Vertical distribution of soil organic carbon content (Guo et al., 2013) and total sulfur content for eight profiles studied here.

(1) For profile A (Northern Beijing Steel Company, sintering plant), the total sulfur contents of the soil vary between $0.01 \mathrm{wt} . \%$ and 0.69 wt.\%, with contents above 0.15 wt.\% in the top $20 \mathrm{~cm}$ and at $60 \mathrm{~cm}$ depth (Fig. 2). Sulfur isotope values of different sulfur species display little variation with depth: Soluble sulfur isotopic compositions shows isotopic values between $16.6 \%$ and $31.3 \%$ VCDT; CRS isotopic compositions show a decrease in $\delta^{34} \mathrm{~S}_{\mathrm{CRS}}$ from $12.6 \%$ o to $7.6 \%$.

(2) Profile B near the rolling plant located east of the Beijing Steel Company, show highly variable total sulfur contents between
0. wt.\% and 0.084 wt.\% (Figs. 2 and 3). Again, soluble sulfur isotopic compositions show a decrease in $\delta^{34} \mathrm{~S}_{\mathrm{CRS}}$ from $6.2 \mathrm{wt}$.\% to $1.8 \%$; CRS isotopic compositions show a decreasing trend in $\delta^{34} \mathrm{~S}$ from $3.4 \mathrm{wt} . \%$ to $-6.8 \%$ (Figs. 2 and 3); the isotopic composition of OBS is $6.3 \%$.

(3) The DLC profile at the power plant, the main area of the Beijing Steel Company, exhibits total sulfur contents between 0.02 wt.\% and 0.6 wt.\% with the top samples showing the highest contents (Fig. 2). Soluble sulfur isotopic compositions show an increase in $\delta^{34} S_{\text {sulfate }}$ from $1.8 \%$ to $26.1 \%$ o (Figs. 3 and 4 ).

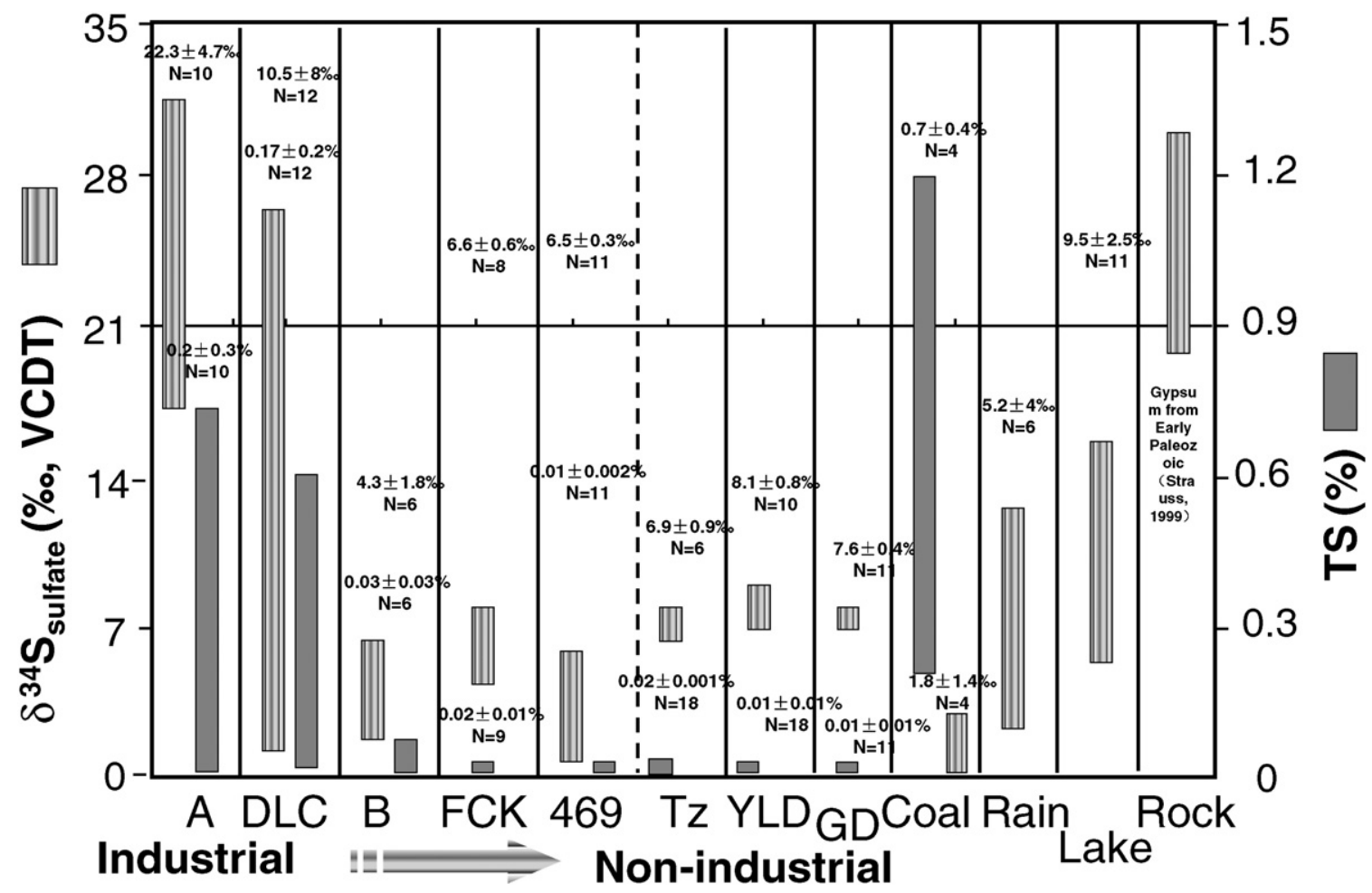

Fig. 3. Distribution of sulfur isotopic composition and TS of this study. 


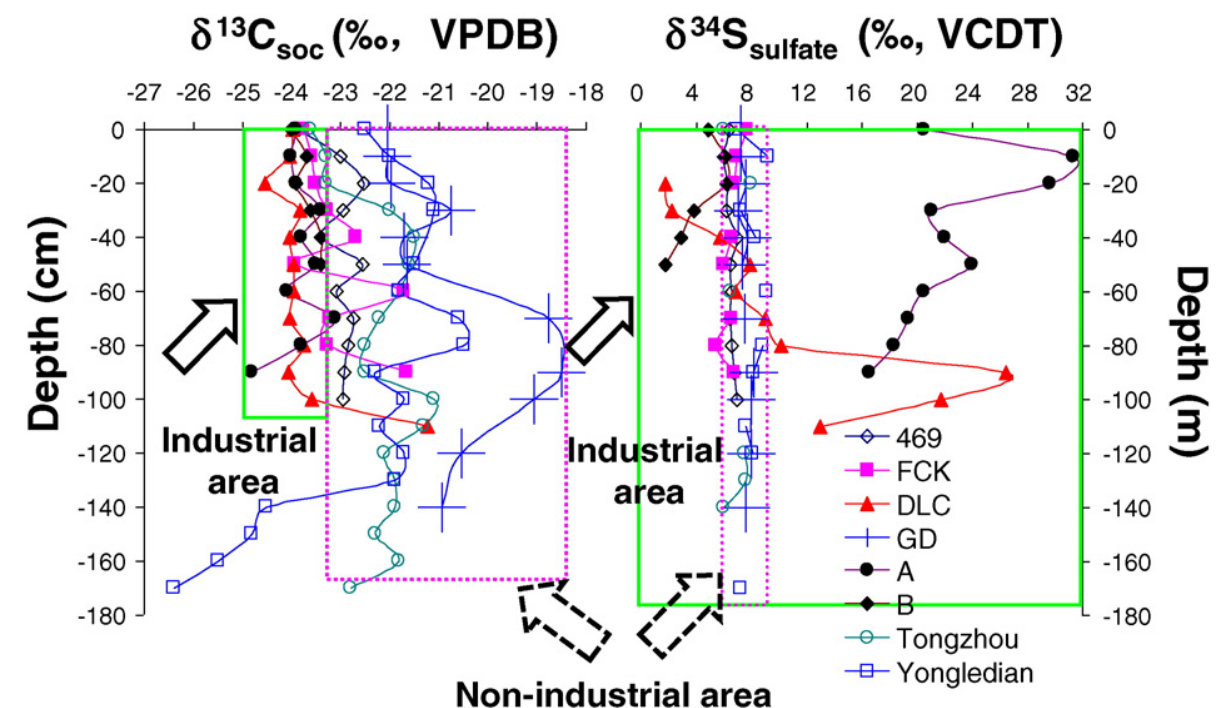

Fig. 4. Vertical distribution of soil organic carbon (Guo et al., 2013) and sulfate sulfur isotopic composition for eight profiles studied here.

(4) The FCK profile is close to the main area of the Beijing Steel Company. Total sulfur contents in the soil vary between $0.007 \mathrm{wt} . \%$ and $0.03 \mathrm{wt}$ \% with the top samples showing the highest contents (Fig. 2). Soluble sulfur isotopic compositions show a decrease in $\delta^{34} S_{\text {sulfate }}$ from $7.7 \%$ o to $5.5 \%$ o (Figs. 3 and 4 ).

(5) The 469 profile at Yongdinghe river area at the Western Beijing Steel Company shows total sulfur contents between 0.008 wt.\% and 0.014 wt.\% with the top samples showing the highest contents (Fig. 2). Soluble sulfur isotopic compositions show similar $\delta^{34} \mathrm{~S}_{\text {sulfate }}$ values between $6.0 \%$ and $6.9 \%$ (Figs. 3 and 4 ).

(6) The total sulfur contents of the Tongzhou soil profile vary between 0.007 wt.\% and 0.04 wt.\% with the top samples showing the highest contents (Fig. 2). Soluble sulfur isotopic compositions exhibit variable $\delta^{34} S_{\text {sulfate }}$ values between $6 \%$ and $8 \%$ o without a significant isotopic trend; CRS isotopic compositions show a decrease in $\delta^{34} \mathrm{~S}_{\mathrm{CRS}}$ from $6.1 \%$ to $1.7 \%$; OBS reveals a $\delta^{34} \mathrm{~S}$ value of $6.5 \%$ (Figs. 3 and 4 ).

(7) The Yongledian profile from the Tongzhou District, considered to be the most natural and least polluted site, shows a total sulfur range from $0.001 \mathrm{wt} . \%$ to $0.03 \mathrm{wt}$.\% (Fig. 2). Soluble sulfur isotopic compositions vary between $7 \%$ and $9.2 \%$ in $\delta^{34} \mathrm{~S}$; the CRS shows $\delta^{34} \mathrm{~S}$ values between $-7.1 \%$ and $5.8 \%$; the isotopic composition of OBS is variable with values between $4.3 \%$ ond $5.6 \%$ (Figs. 3 and 4).

(8) The Guadi profile at Shilou town, the agricultural area of the Fangshan District near the Beijing urban area, reveals highly variable total sulfur contents between $0.005 \mathrm{wt} . \%$ and 0.025 wt.\% (Fig. 2); soluble sulfur isotopic compositions vary between $7.1 \%$ and $8.2 \%$ in $\delta^{34} \mathrm{~S}$; CRS exhibits variable isotopic compositions with $\delta^{34} \mathrm{~S}$ values between $8.2 \%$ and $9 \%$; OBS

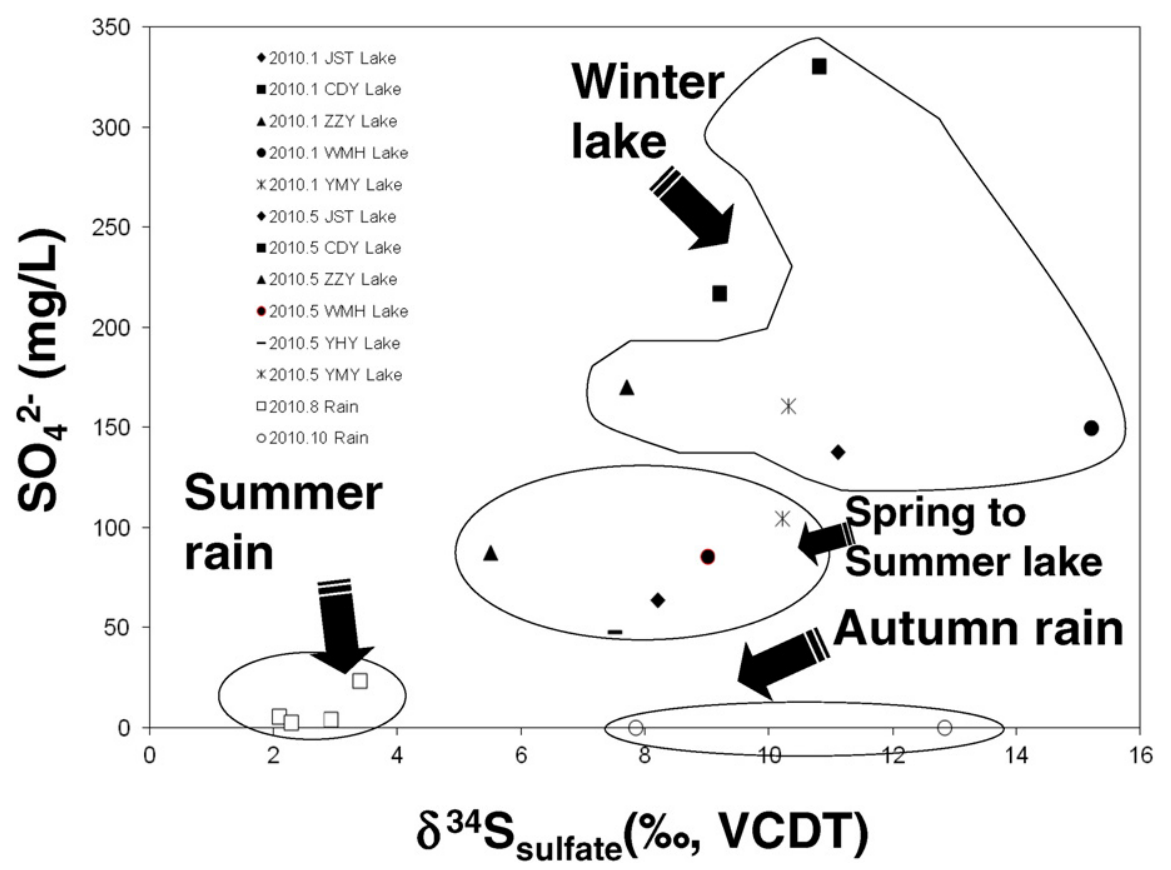

Fig. 5. Cross-plot of $\delta^{34} \mathrm{~S}_{\text {sulfate }}$ and $\mathrm{SO}_{4}^{2-}(\mathrm{mg} / \mathrm{L})$ for samples from lakes and rain in Beijing (2010). 
shows $\delta^{34}$ S values from $0.4 \%$ to $4.9 \%$ (Figs. 3 and 4 ) without a significant isotopic trend.

(9) The $\delta^{34} S_{\text {sulfate }}$ values of the lake water range from $7.7 \%$ o to $15.2 \%$ in January, and from $5.5 \%$ o to $10.2 \%$ in May. $\mathrm{SO}_{4}^{2-}, \mathrm{Cl}^{-}, \mathrm{NO}_{3}^{-}$concentrations range from $138 \mathrm{mg} / \mathrm{L}$ to $330.6 \mathrm{mg} / \mathrm{L}$, from $5 \mathrm{mg} / \mathrm{L}$ to $243 \mathrm{mg} / \mathrm{L}$, from $3.7 \mathrm{mg} / \mathrm{L}$ to $22.9 \mathrm{mg} / \mathrm{L}$, respectively, in January, and from $47.8 \mathrm{mg} / \mathrm{L}$ to $216 \mathrm{mg} / \mathrm{L}$, from $18 \mathrm{mg} / \mathrm{L}$ to $224 \mathrm{mg} / \mathrm{L}$, from $4 \mathrm{mg} / \mathrm{L}$ to $21 \mathrm{mg} / \mathrm{L}$, respectively, in May. The analytical results of $\mathrm{Cl}^{-}, \mathrm{SO}_{4}^{2-}$ and $\mathrm{NO}_{3}^{-}$concentrations provide information about the source of surface water, affected by human and biological activities.

(10) The $\delta^{34} \mathrm{~S}_{\text {sulfate }}$ values of rain samples range from 2.1 to $3.4 \%$ in August, and from 7.8 to $12.8 \%$ in October, $\mathrm{SO}_{4}^{2-}$ concentrations range from $2.8 \mathrm{mg} / \mathrm{L}$ to $23.5 \mathrm{mg} / \mathrm{L}$ in August and from $18.4 \mathrm{mg} / \mathrm{L}$ to $62.9 \mathrm{mg} / \mathrm{L}$ in October (Fig. 5).

(11) The $\delta^{34} \mathrm{~S}_{\text {sulfate }}$ values of coal samples range from $2.1 \%$ o to $2.9 \%$; the $\delta^{34}$ SCRS values range from $-2.9 \%$ o to $-0.8 \%$; the $\delta^{34}$ SOBS values range from $-0.4 \%$ o to $4 \%$; TS contents range from $0.12 \%$ to $1.15 \%$.

\section{Discussion}

Eight profiles studied here show different environmental conditions. Soil profile A is located near a sintering plant in the northwest part of the Beijing Steel Company, close to the main smoke stack. The second soil profile (B) is located near a rolling plant east of the main area of the Northern Beijing Steel Company. The DLC profile (C) is located at the power plant, the main area of the Beijing Steel Company. Profiles A, B and C have likely experienced a long history of contributions by different anthropogenic contaminants, ranging from heavy metals to organic waste since the Northern Beijing Steel Company was founded in 1919.

The FCK (D) profile is located at the waste warehouse, $400 \mathrm{~m}$ east of the main area of the Beijing Steel Company. The 469 (E) profile is located close to the steel company at the west bank of the Yongding River. Profile F is located at Tongzhou District, south-eastern Beijing, and represents an agricutural area with wheat and corn growing at the time of sampling. Historical records revealed contributions of organic waste waters to the soil for irrigation purposes. Profile G located at Yongledian, south-eastern Beijing and profile Guadi $(\mathrm{H})$ located at Fangshan, southwestern Beijing, are both the most natural and least polluted sites (Guo et al., 2013).

\subsection{Environmental framework}

In order to constrain their possible contributions to the soil profiles investigated here, different sample sets were studied in addition to the soil samples, notably coal, lake water and precipitation from the Beijing area.

In general, coals from North China are characterized by a lower sulfur content and higher $\delta^{34} \mathrm{~S}$ values than those from South China (Hong et al., 1992). $\delta^{34} \mathrm{~S}_{\mathrm{OBS}}$ values of coals from Inner Mongolia, North China, vary from $+8.9 \%$ o to $+11.5 \%$ o (Duan, 1995). The pyrite sulfur isotopic composition of coal from Shanxi Province, North China, ranges from $-20.9 \%$ o to $+5.8 \%$.

Usually, Beijing's industrial companies use coal from North China.

The Beijing Steel Company area is located at the foot of the West Hills in Beijing. Carbonates and gypsum of Lower Paleozoic age that are cropping out widely in the western and northern mountain area of Beijing (Xie, 1990) have to be considered as a distal sulfur source. $\delta^{34} S_{\text {sulfate }}$ values of gypsum from the Early Paleozoic vary from $20 \%$ o to 30\%。 (Strauss, 1999).

Sulfate abundances and sulfur isotopic compositions in Beijing lakes investigated in 1994. Concentrations varied from $14.7 \mathrm{mg} / \mathrm{L}$ to $38.7 \mathrm{mg} / \mathrm{L}$ (average: $24.52 \pm 3.9 \mathrm{mg} / \mathrm{L}$ ) and $\delta^{34} \mathrm{~S}_{\text {sulfate }}$ values displayed a range between $6.2 \%$ o to $9.3 \%$ o (average: $7.5 \pm 0.8 \%$ ) (Chu, 2000). In contrast, higher sulfate abundances were determined here around an average value of $189.9 \pm 80 \mathrm{mg} / \mathrm{L}(\mathrm{n}=5)$ in January, 2010 to $101 \pm 60 \mathrm{mg} / \mathrm{L}$ $(\mathrm{n}=6)$ in May, 2010 (Table S2). The respective $\delta^{34} S_{\text {sulfate }}$ values for lake waters in 2010 vary from $11 \pm 2.7 \%$ o $(n=5)$ in January to $8.3 \pm$ $1.6 \%$ 。 $(n=6)$ in May.

Highly variable sulfate concentrations and differing sulfate sulfur isotopes were reported for Beijing precipitation over the past 16 years. Concentrations between 6.8 and $16.3 \mathrm{mg} / \mathrm{L}$ were measured for rain samples from 1994 (Chu, 2000). Xu and Han (2009) disclosed that the $\mathrm{SO}_{4}^{2-}$ concentration in rain from Beijing in 2006 varied from $6.24 \mathrm{mg} / \mathrm{L}$ to $94.75 \mathrm{mg} / \mathrm{L}$ (average: $30.34 \pm 20.45 \mathrm{mg} / \mathrm{L}, \mathrm{n}=16$ ). A wider range between $8.9 \pm 9.8 \mathrm{mg} / \mathrm{L}(\mathrm{n}=4)$ in August and $40.6 \pm 31.5 \mathrm{mg} / \mathrm{L}(\mathrm{n}=2)$ was determined here for rain samples from October in 2010. Sulfate sulfur isotopes for rain in 1994 showed a $\delta^{34} S_{\text {sulfate }}$ value of $6.1 \%$ and a range in $\delta^{34} S_{\text {sulfate }}$ between $2.7 \pm 0.6 \%$ 。 $(n=4)$ in August and $10.3 \pm$ $3.5 \%$ 。 $(\mathrm{n}=2)$ in October 2010.

Concentrations of dissolved sulfate in rain and lake waters clearly display a temporal evolution with higher abundances in 2010 when compared to 1994. Similarly, sulfate concentrations are higher in the winter than in the summer.

\subsection{Sulfur in Beijing soils}

The $\delta^{34} S_{\text {sulfate }}$ values of soil from the profiles B, C, D, E, F an G are quite similar compared with those of lake and rain water samples confirming the results of previous studies (Chu, 2000; Xu and Han, 2009), but sulfate abundances are higher compared with the results of Chu (2000) and Xu and Han (2009). The results reflect that the sulfate abundances of rain in 2010 are higher than in 1994, which discloses that the $\mathrm{SO}_{4}^{2-}$ pollution is more serious compared with 16 years before. The results suggest that coal combustion in winter leads to higher $\delta^{34} \mathrm{~S}_{\text {sulfate }}$ values and higher sulfate abundances in soil in winter compared to summer (Fig. 5).

Furthermore, the relatively high temperature in summer leads to a significant amount of biological sulfur released from surface waters.

The eight profiles investigated for the present study show different environmental conditions and sulfur sources.

A. At profile $A, \delta^{34} S_{\text {sulfate }}$ values of topsoil horizons generally decrease with depth from 31.3 to $16.6 \%$ (Tables S1, S2, Figs. 3 and 4), and the total soil sulfur contents are highly variable with values between 0.01 and $0.69 \mathrm{wt} . \%$. Total soil sulfate contents and $\delta^{34} \mathrm{~S}_{\text {sulfate }}$ values of samples from profile A display a direct correlation $\left(\mathrm{R}^{2}=\right.$ 0.82). The high $\delta^{34} S_{\text {sulfate }}$ values and the high sulfate contents of these samples indicate that at least four sources could have contributed to the sulfate in the top and deep soil (Figs. 6 and 7): atmospheric deposition, biological sulfur (Chu, 2000; Xiao and Liu, 2002; Xu and Han, 2009), dissolution of gypsum, or oxidation of sulfide minerals in coalbearing strata. $\delta^{34} \mathrm{~S}_{\text {sulfate }}$ values from atmospheric deposition were generally lower than $10 \%$ (Fig. 7), hence, respective values are substantially lower than those at profile A. Consequently, the ${ }^{34} \mathrm{~S}$-rich soil samples at profile A suggest that the sources of sulfate are either from the dissolution of gypsum, from sea sulfate, and/or from biological sulfur (Figs. 6 and 7). The influx of atmospheric $S$ deposition is detected to a depth of more than $1 \mathrm{~m}$. The $\delta^{34} \mathrm{~S}_{\mathrm{CRS}}$ values are always lower than the $\delta^{34} \mathrm{~S}_{\text {sulfate }}$ and $\delta^{34} \mathrm{~S}_{\mathrm{OBS}}$ values in the same samples (Table S1), while the $\delta^{34} \mathrm{~S}_{\text {sulfate }}$ and $\delta^{34} \mathrm{~S}_{\mathrm{CRS}}$ values follow the same trend with increasing depth. This suggests that the $\mathrm{FeS}_{2}$ results from the dissimilatory reduction of soil sulfate. For the Northern Steel company location, $\delta^{34} S_{\text {sulfate }}$ values are systematically higher compared to the rest of profiles, indicating that the mobile soluble $\mathrm{S}$ fraction carries a recent industrial signature enriched in ${ }^{34} \mathrm{~S}$, whereas organic $\mathrm{S}$ can be derived from the incorporation of hydrogen sulfide from sulfate reduction, once Fe is exhausted in the soil, which is rather depleted in ${ }^{34} \mathrm{~S}$, especially in the soil profile at profile $\mathrm{A}$. The $\delta^{34} \mathrm{~S}_{\mathrm{OBS}}$ value of $2.8 \%$ is much lower than the $\delta^{34} S_{\text {sulfate }}$ value of $29.6 \%$. In Alberta, Canada, in the vicinity of sour 


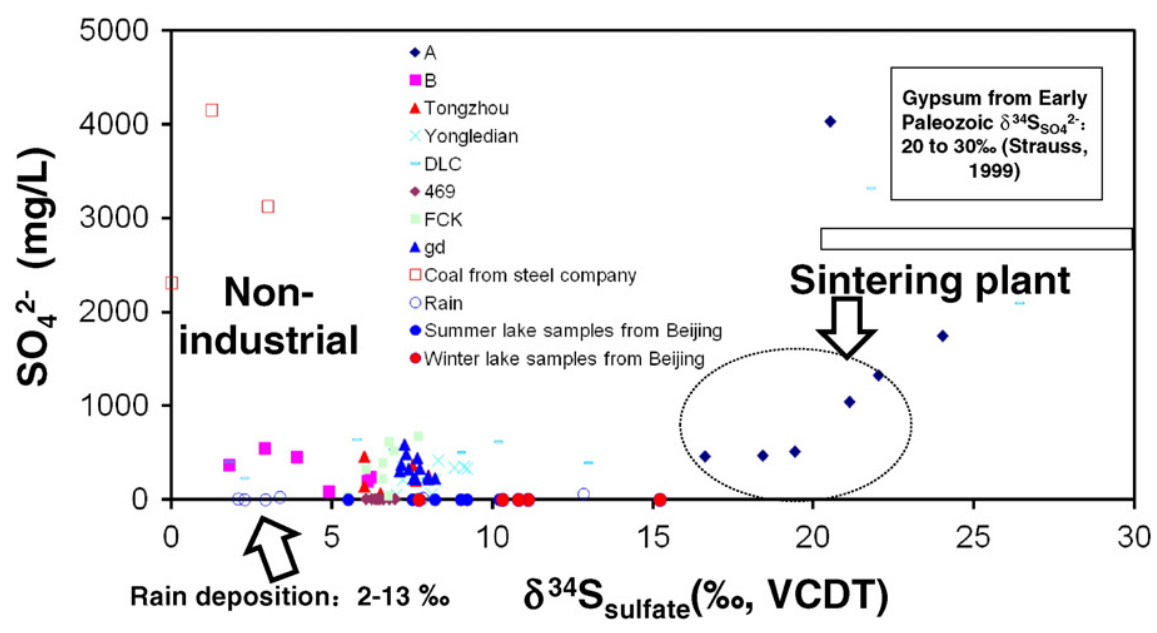

Fig. 6. Cross-plot of $\delta^{34} \mathrm{~S}_{\text {sulfate }}$ and $\mathrm{SO}_{4}^{2-}(\mathrm{mg} / \mathrm{L})$ from lakes and soil section samples.

gas processing operations, $\mathrm{SO}_{2}$ emissions typically show $\delta^{34} \mathrm{~S}$ values near $+20 \%$. The reason for the heavy $\delta^{34} \mathrm{~S}$ values in Alberta is a consequence of the sour gas which reflects subsurface reaction with isotopically heavy Devonian evaporites (Legge and Krouse, 1992). The mean $\mathrm{S}$ isotope composition of the soil shifts towards the values of industrial emissions, depending on the extent to which penetration of industrial $\mathrm{S}$ occurs. The $\delta^{34} \mathrm{~S}$ values and TS of topsoil horizons generally decrease with depth (Fig. 4). This suggests that up to $50 \%-80 \%$ of industrial S is stored in the deep soil or indicates two different natural background with distinct $\delta^{34} \mathrm{~S}$ values.

$B$. At profile $B$, the penetration does not seem to be as strong as at profile A. Similar trends with decreasing depth are apparent: $\delta^{34} S$ values of topsoil horizons generally decrease with depth similar to profile A (Fig. 4) and $\delta^{34} S_{\text {sulfate }}$ values of topsoil horizons generally decrease with depth from $6.2 \%$ o to $1.8 \%$. The soil total sulfur contents range between 0.006 and $0.084 \mathrm{wt} . \%$. The reasons are: (1) Profile B is close to the Rolling plant and a little further from the Sintering plant; (2) Profile $B$ is outside of Beijing steel company rolling plant area, and there is a field with some small trees, so that $\delta^{34} \mathrm{~S}_{\text {sulfate }}$ values of soil section B generally decreased with depth just like section A, but there are lower sulfur contents and lower $\delta^{34} \mathrm{~S}$. According to the cross-plot of $\delta^{34} \mathrm{~S}_{\text {sulfate }}$ and $\mathrm{SO}_{4}^{2-}(\mathrm{mg} / \mathrm{L})$ from lakes, rain and soil sections samples (Fig. 6), we found that ${ }^{34} \mathrm{~S}$-depleted $\delta^{34} \mathrm{~S}_{\text {sulfate }}$ values show that sulfate of sources from profile $B$ is mainly from coal burning or oxidation of sulfide mineral, which is mainly from industrial waste and coal burning.

C. Soil total sulfate content and $\delta^{34} \mathrm{~S}_{\text {sulfate }}$ values display a positive correlation $\left(R^{2}=0.28\right)$. The high $\delta^{34} S_{\text {sulfate }}$ values and sulfate contents of the samples indicate that coal burning, oxidation of sulfide mineral in coal containing strata, atmospheric deposition, dissolution of gypsum, etc. have contributed to sulfate in the topsoil and deep soil.

D. Tongzhou, Yongledian, Guadi profiles: $\delta^{34} \mathrm{~S}_{\text {sulfate }}$ values (6\% and $8 \%$ ) of soil section Tongzhou (7\% and 9.2\%), of soil section Yongledian (7.3\% and $8.2 \%$ ) and of soil section Guadi(7.1\% and $8.2 \%$ ) do not decrease with depth (Fig.4), which is different compared with the profiles taken at the profiles A, B and DLC. The sulfate contents are lower (Tongzhou: 0.007 wt.\% to 0.04 wt.\%; Yongledian: 0.001 wt.\% to 0.03 wt.\%; Guadi: 0.005 wt.\% to 0.025 wt.\%), so that the $\delta^{34} S_{\text {sulfate }}$ values from the section Tongzhou and Yongledian disclose that topsoil and

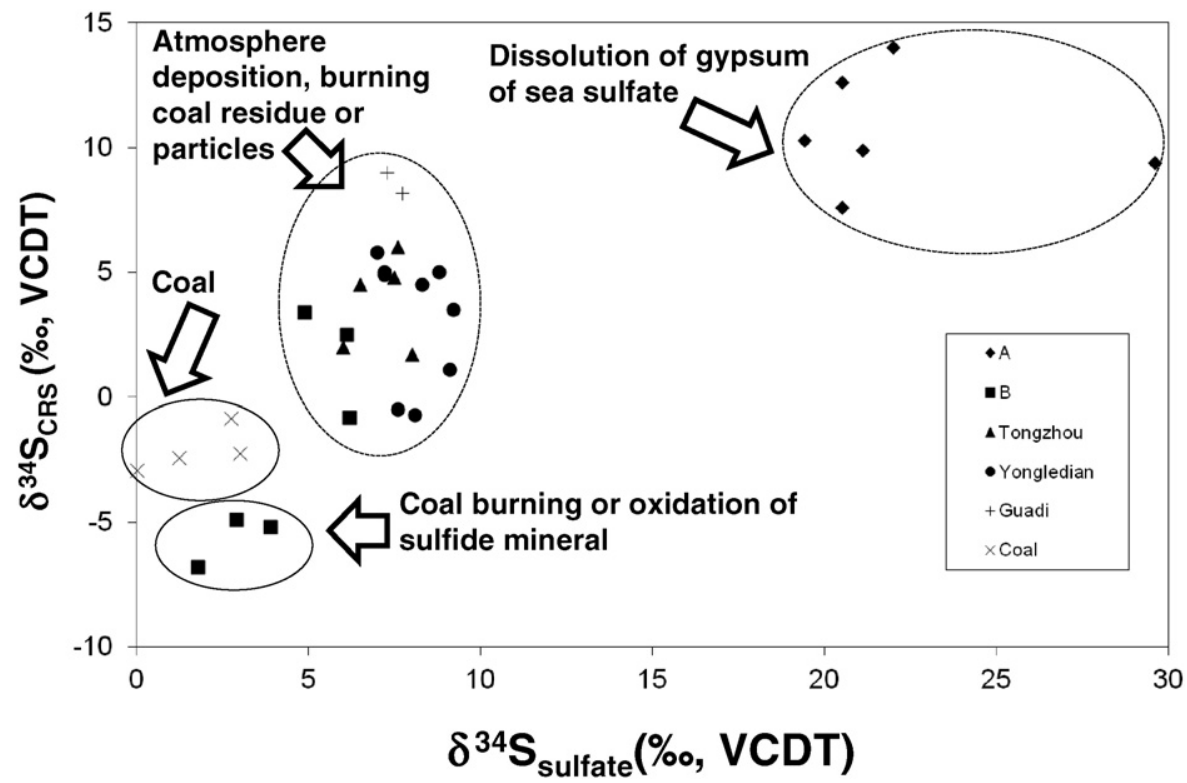

Fig. 7. Cross-plot of $\delta^{34} S_{\text {Sulfate }}$ and $\delta^{34} S_{\text {CRS }}$ from coal and soil section samples. 
deep soil samples have not been polluted and kept the original natural characteristics. The positive $\delta^{34} \mathrm{~S}_{\text {sulfate }}$ values suggest a contribution of oceanic $\mathrm{SO}_{4}^{2-}$. Stable $\delta^{34} \mathrm{~S}_{\text {sulfate }}$ values close to sulfate from lake and rain water show that sulfate is derived from atmospheric deposition and biological sulfur (Figs. 6 and 7).

E. The $\delta^{34} S_{\text {sulfate }}$ values of topsoil horizons at the profile 469 slightly increase with depth from $5.5 \%$ to $7.7 \%$ at profile D (Tables S1, S2, Fig. 4), and soil total sulfur contents are highly variable with values between $0.03 \mathrm{wt} . \%$ and $0.007 \mathrm{wt} . \%$. Soil total sulfate content and $\delta^{34} \mathrm{~S}_{\text {sulfate }}$ display a light correlation $\left(\mathrm{R}^{2}=0.20\right)$ at profile FCK. $\delta^{34} \mathrm{~S}_{\text {sulfate }}$ values of topsoil horizons slightly increase with depth from $6.4 \%$ 。 to $6.9 \%$ at profile E (Tables S1, S2, Fig. 4), and soil total sulfur contents are highly variable between $0.013 \mathrm{wt} . \%$ and $0.008 \mathrm{wt} . \%$. Soil total sulfate contents and $\delta^{34} S_{\text {sulfate }}$ values display no correlation $\left(R^{2}=0.006\right)$. In the deeper mineral soil of the two locations (469, FCK profiles) close to the steel company plant, the $\delta^{34} \mathrm{~S}$ values of the soluble sulfur and CRS are intermediate between those of the remote or natural background location (Tongzhou, Yongledian, Guadi) and the industrial area (A, B, DLC). Stable $\delta^{34} S_{\text {sulfate }}$ values show that sulfate is from atmospheric deposition, coal combustion residues or particles (Figs. 6 and 7).

Differences in $\delta^{34} \mathrm{~S}$ values of $\mathrm{S}$ fractions are caused by kinetic isotope effects and possibly isotope exchange reactions involved in chemical and biological transformations (Legge and Krouse, 1992), as shown by the results from the deep soil profiles of Tongzhou, Yongledian and Guadi, where a little difference in the $\delta^{34} S$ values within the soil profile can be observed.

\section{Conclusions}

$\delta^{34} S_{\text {sulfate }}$ values from the soil sections taken at the profiles A, B and DLC disclose that topsoil and deep soil samples have been polluted, especially the profile A area. The amount of industrially produced sulfur is elevated in these soils. The $\delta^{34} \mathrm{~S}_{\text {sulfate }}$ values from the sections Tongzhou, Yongledian and Guadi reveal that topsoil and deep soil samples have been not polluted and kept the original natural characteristics. Two other profiles (469, FCK) located outside of the main industrial area display sulfur isotope profiles between those from industrial and nonindustrial areas.

This study suggests that an assessment of the vertical distribution of sulfur concentration and sulfur isotopic composition of bulk soil in soil profiles from industrial and non-industrial areas can trace the sources and fate of different sulfur species in soil.

\section{Acknowledgments}

Analytical work was performed at the Institut für Geologie und Paläontologie, Westfälische Wilhelms-Universität Münster, Germany, and Artur Fugmann, Andreas Lutter and Jianli Wang are thanked for their help in the laboratory. Jun Yang, Hanzhi Zhang, Chunyu Wang, and Chukwunonso Peter Okoli are also gratefully acknowledged in the stimulating discussions. GQ acknowledges financial support by the $\mathrm{Na}-$ tional Basic Research Program (973) of China (No. 2014CB238906), the Sino-German program Center (GZ1055), the Joint ISF-NSFC program (No. 4151101008), and NSFC (Grant No. 41450110460).

Supplementary data to this article can be found online at http://dx. doi.org/10.1016/j.gexplo.2015.11.010.

\section{References}

ASTM, 1977. Standard test methods for total sulfur in the analysis samples of coal and coke. Ann. Book ASTM Standards 05.05, pp. 333-336.

Canfield, D.E., Raiswell, R., Westich, J.T., et al., 1986. The use of chromium reduction in the analysis of reduced inorganic sulfur sediments and shales. Chem. Geol. 54, 149-155.

Chu, X., 2000. Sulfur isotopic compositions and environmental geochemistry of surface water in Beijing District. Quat. Sci. 20 (1), 87-97.
Dogramaci, S.S., Herczeg, A.L., Schiff, S.L., Bone, Y., 2001. Controls on $\delta^{34}$ S and $\delta^{18} O$ of dissolved sulfate in aquifers of the Murray Basin, Australia and their use as indicators of flow processes. Appl. Geochem. 16, 475-488.

Duan, Y., 1995. Stable isotopic characteristics of Chinese coal. Coal Geol. Explor. 23 (1), 29-34.

Galuszka, A., 2005. The chemistry of soils, rocks and plant bioindicators in three ecosystems of the holy cross mountains, Poland. Environ. Monit. Assess. 110, 55-70.

Guo, Q., Strauss, H., Chen, T., Zhu, G., Yang, J., Lei, M., Zhou, X., Peters, M., Xie, Y., Zhang, H. Wei, R., Wang, C., 2013. Tracing the source of Beijing soil organic carbon: a carbon isotope approach. Environ. Pollut. 176, 208-214.

Hong, Y., Zhang, H., Zhu, Y., Piao, H., Jiang, J., Zeng, Y., Liu, G., 1992. Sulfur isotope composition in Chinese coals and sulfur isotope fractionation during coal combustion. Sci. China (B) 22 (8), 868-873 (in Chinese with English abstract).

Knöller, K., Fauville, A., Mayer, B., Strauch, G., Friese, K., Veizer, J., 2004. Sulfur cycling in an acid mining lake and its vicinity in Lusatia, Germany. Chem. Geol. 204, 303-323.

Knöller, K., Trettin, R., Strauch, G., 2005. Sulphur cycling in the drinking water catchment area of Torgau-Mockritz (Germany): insights from hydrochemical and stable isotope investigations. Hydrol. Process. 19, 3115-3165.

Krouse, H.R., 1989. Sulfur isotope studies of the pedosphere and biosphere. In: Rundel, P.W., Ehleringer, J.R., Nagy, K.A. (Eds.), Stable isotopes in Ecological Research. SpringerVerlag, New York, pp. 424-444.

Krouse, H.R., Tabatabai, M.A., 1986. In: Tabatabai, M.A. (Ed.), Stable Sulfur Isotopes, Sulfur in Agriculture. American Society of Agronomy/Crop Science society of America/Soil Science Society of America, Madison, WI, pp. 169-205.

Krouse, H.R., Legge, A.H., Brown, H.M., 1984. Sulfur gas emissions in the boreal forest: the west whitecourt case study: V. Stable sulfur isotopes. Water Air Soil Pollut. 22, 321.

Krouse, H.R., Stewart, W.B., Grinenko, V.A., 1991. Pedosphere and biosphere. In: Krouse, H.R., Grinenko, V.A. (Eds.), Stable Isotopes: Natural and Anthropogenic Sulfur in the Environment. John Wiley and Sons, Chichester, pp. 267-306.

Legge, A.H., Krouse, H.R., 1992. An assessment of the environmental fate of industrial sulfur in a temperate pine forest ecosystem. Atmospheric Chemistry Papers From the 9th World Clean Air Congress Towards the Year 2000, Paper 1U-22B.01.

Liu, C., Lang, Y., TakeSa, H., Wu, J., Li, S., 2008. Identification of anthropogenic and natural inputs of sulfate and chloride into the karstic ground water of Guiyang, SW China: combined $\delta^{37} \mathrm{Cl}$ and $\delta^{34} \mathrm{~S}$ approach. Environ. Sci. Technol. 42, 5421-5427.

Mayer, B., 1993. Untersuchungen zur Isotopengeochemie des Schwefels in Waldböden und neu Gebildetem Grundwasser Unter Wald, GSF-Bericht 2/93. GSF-Forschungszentrum für Umwelt und Gesundheit.

Mayer, B., Fritz, P., Priietzel, J., Krouse, H.R., 1995. The use of stable sulfur and oxygen isotope ratios for interpreting the mobility of sulfate in aerobic forest soils. Appl. Geochem. 10, 161-173.

Mayer, B., Rock, L., Hogberg, L., Jackson, L., Varner, M., Shanley, J.B., Bailey, S.W., Mitchell, M.J., 2004. Delineating sources of sulfate and nitrate in rivers and streams by combining hydrological, chemical and isotopic techniques (IAEA-CN-118/57). Isotopes in Environmental Studies - Aquatic Forum 2004, p. 148.

Migazewski, Z.M., Gałuszka, A., Michalik, A., Dołegowska, S., Migazewski, A., Hałas, S. Trembaczowski, A., 2013. The use of stable sulfur, oxygen and hydrogen isotope ratios as geochemical tracers of sulfates in the Podwis'nio'wka acid drainage area (South-Central Poland). Aquat. Geochem. 19, 261-280.

Migazewski, Z.M., Gałuszka, A., Dołegowska, S., Hałas, S., Krzciuk, K., Gebus, B. 2015. Assessing the impact of Serwis mine tailings site on farmers' wells using element and isotope signatures (Holy Cross Mountains, south-central Poland). Environ. Earth Sci. http://dx.doi.org/10.1007/ s12665-015-4067-6.

Novák, M., Bottrell, S.H., Přechová, E., 2001. Sulfur isotope inventories of atmospheric deposition, spruce forest floor and living Sphagnum along a NW-SE transect across Europe. Biogeochemistry 53, 23-50.

Novák, M., Michel, R.L., Přechová, E., Štěpánová, E., 2004. The missing flux in a ${ }^{35}$ S budget for the soils of a small polluted catchment. Water Air Soil Pollut. Focus 4, 517-529.

Otero, N., Soler, A., 2002. Sulfur isotopes as tracers of the influence of potash mining in groundwater salinisation in the Llobregat basin (NE Spain). Water Res. 36, 3989-4000.

Shanley, J.B., Mayer, B., Mitchell, M.J., Michel, R.L., Bailey, S., Kendall, C., 2005. Tracing sources of streamwater sulfate during snowmelt using $\mathrm{S}$ and $\mathrm{O}$ isotope ratios of sulfate and ${ }^{35}$ S activity. Biogeochemistry 76, 161-185.

Strauss, H., 1999. Geological evolution from isotope proxy signals - sulfur. Chem. Geol. $161,89-101$.

Szynkiewicz, A., Witcher, J.C., Modelska, M., Borrok, D.M., Pratt, L.M., 2011. Anthropogenic sulfate loads in the Rio Grande, New Mexico (USA). Chem. Geol. 283, 194-209.

Thompson, A., Bottrell, S., 1998. Sulfur isotopic investigation of a polluted raised bog and the uptake of pollutant sulfur by Sphagnum. Environ. Pollut. 101, 201-207.

Van Stempvoort, D.R., Fritz, P., Reardon, E.J., 1992. Sulfate dynamics in upland forest soils, central and southern Ontario, Canada: stable isotope evidence. Appl. Geochem. 7, 159-175.

Winner, W.E., Smith, C.L., Koch, G.W., Mooney, H.A., Bewley, J.D., Krouse, H.R., 1981. Rates of emission of $\mathrm{H}_{2} \mathrm{~S}$ from plants and patterns of stable sulfur isotope fractionation. Nature 289, 672.

Xiao, H., Liu, C., 2002. Sources of nitrogen and sulfur in wet deposition at Guiyang, southwest China. Atmos. Environ. 36, 5121-5130.

Xie, D., 1990. The lower Palaeozoic Erathem of Beijing. Beijing Geol. 2, 1-28.

$\mathrm{Xu}, \mathrm{Z}$., Han, G., 2009. Chemical and strontium isotope characterization of rainwater in Beijing, China. Atmos. Environ. 43, 1954-1961. 